\title{
A Theory of Democratic Adjudication: TOWARDS A REPRESENTATIVE, ACCOUNTABLE AND INDEPENDENT JUDICIARY
}

\author{
K.D. EWING
}

This article explores how the judiciary. particularly in the modern British context, could increase its representational capacity and its accountability while maintaining its independence. The analysis includes an examination of the functions and principles underlying the judiciary, as well as the current movement for judicial reform in Britain. The author suggests a number of ways for judges to be made accountable in order to promote dialogue between judges and the public, including the appearance before a Select Committee. It is also suggested that a Registrar of Judicial Interests would strengthen both judicial independence and accountability. The author further notes that the creation of a Judicial Appointments Commission, not only to monitor but also to appoint judges, would protect the judiciary's independence from the political sphere.
Cet article explore comment le système judiciaire, surtout dans le contexte de la Grande-Bretagne moderne, pourrait améliorer sa capacité représentative et sa responsabilité tout en conservant son indépendance. $L$ 'analyse comprend l'examen des fonctions et des principes sous-jacents au système judiciaire de même que les mouvements actuels de réforme judiciaire en Grande-Bretagne. $L$ 'auteur suggère plusieurs façons de responsabiliser les juges afin de promouvoir le dialogue entre les juges et le public, y compris leur demander de comparaitre devant le comité spécial. Il y est aussi suggéré qu'un registraire des intérêts judiciaires renforce autant l'indipendance que l'imputabilité du système judiciaire. L'auteur fait aussi remarquer que la création d'une Commission de magistrature qui aurait non seulement un rôle de suivi, mais qui verrait aussi à la nomination des juges, pourrait protéger l'indépendance du système judiciaire des sphères politiques.

\section{TABLE OF CONTENTS}

I. INTRODUCTION . . . . . . . . . . . . . . . . 709

II. THE JUdiCIAL FUnCTION $\ldots \ldots \ldots \ldots \ldots \ldots \ldots \ldots \ldots 710$

A. JUDGeS AS PRIMARY LegISLATORS:

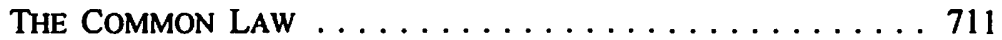

B. JUDGES AS SECONDARY LEGISLATORS:

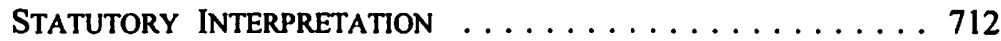

III. THE JUDICIAL FUNCTION AND HUMAN RIGHTS $\ldots \ldots \ldots \ldots \ldots 713$

A. THE HUMAN RIGHTS ACT 1998:

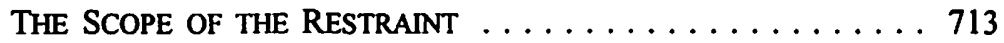

B. THE HUMAN RIGHTS ACT 1998:

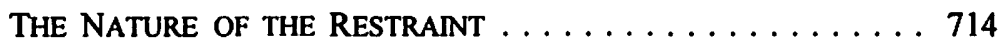

IV. AN (UN)REPRESENTATIVE JUdICIARY $\ldots \ldots \ldots \ldots \ldots \ldots \ldots 716$

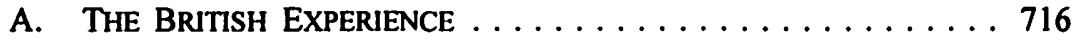

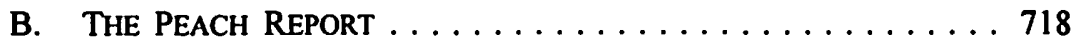

V. A REPRESENTATIVE JUDICIARY: OPTIONS FOR CHANGE . . . . 719

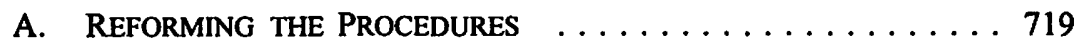

B. TRANSForming the Procedures $\ldots \ldots \ldots \ldots \ldots \ldots \ldots 720$

VI. AN (UN)ACCOUNTABLE JUdICIARY $\ldots \ldots \ldots \ldots \ldots \ldots \ldots \ldots 721$

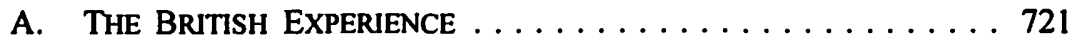

Professor of Public Law, King's College, University of London. 
B. THE Locaball CASE . . . . . . . . . . . . . . . . . . . 722

VII. AN ACCOUNTABLE JUDICIARY: OPTIONS FOR CHANGE . . . . . . 723

A. Voluntary AND SELECTIVE SCRUTINY . . . . . . . . . 724

B. MANDATORY AND UNIVERSAL SCRUTINY . . . . . . . . . 725

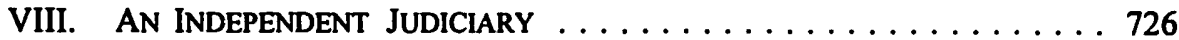

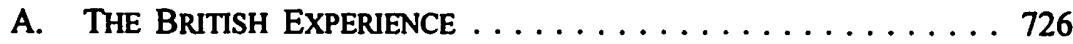

B. JUDICIAL INDEPENDENCE AND

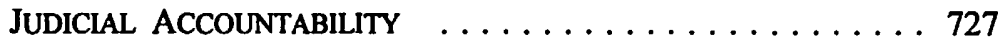

IX. AN INDEPENDENT JUDICIARY: OPTIONS FOR CHANGE . . . . . . 728

A. A JUdiciAl APPOINTMENTS COMMISSION . . . . . . . . . . . 729

B. INSTITUTIONAL SEPARATION: A SUPREME COURT . . . . . . . 730

X. Conclusion ..................... 732

\section{INTRODUCTION}

It is a most remarkable feature of liberal democracy that there has not yet developed a convincing democratic theory of adjudication. As a community, we have developed a sophisticated theory of representative democracy, by which we take it for granted that our parliaments will be elected by a process of universal suffrage, that our voices will be heard in national affairs through the medium of elected representatives, and that our elected representatives will be accountable to us on a regular basis for the way in which they represent our interests. Judges, on the other hand, have escaped this process of democratization, despite the fact that they exercise great powers, and despite the fact that (in Britain) these powers have been significantly increased by the Human Rights Act $1998^{1}$ which incorporates the European Convention on Human Rights ${ }^{2}$ into domestic law. The purpose of this article is to explore how the exercise of such powers can be reconciled with basic and fundamental principles of representative and accountable government, in a manner which respects the overriding need to sustain the independence of the judiciary. This requires a consideration of what it is that judges do, and an examination of the principles by which this activity should be underpinned, as a contribution to the development of a theory of democratic adjudication.

Although there is a serious want of such a theory, this is not to deny that the role of the judiciary has been a cause for concern. In recent years, much of this concern has been expressed by the Labour Party, which has as much reason as anyone to lament the performance of the courts. ${ }^{3}$ In 1989 , the Labour Party, then in opposition, proposed the creation of a new Department of Legal Administration which would be "responsible for all courts and tribunals; for court procedures; the organization, training and appointment

(U.K.), 1998, c. 42.

Council of Europe, 4 November 1950, Eur. T.S. No. 5.

Judicial decisions threatened the very existence of the Party (Amalgamated Society of Railway Servants v. Osborne, [1910] A.C. 87 (H.L.)); disrupted the activities of Labour local authorities (Roberts v. Hopwood, [1925] A.C. 578 (H.L.)); and frustrated the activities of Labour ministers and statutory bodies established by the Labour government in the 1970s (Secretary of State for Education v. Tameside MBC, [1977] A.C. 1014 (H.L.); Laker Airways v. Department of Trade, [1977] Q.B. 643 (C.A.), Grunwick Processing Laboratories v. ACAS, [1978] I.C.R. 231 (H.L.); to say nothing of the way that trade unions have been undermined periodically. 
of the legal profession, magistracy and judiciary." 4 The Party also proposed that steps be taken to establish "racial and sexual equality throughout the legal profession and the administration of the law," and that "the judges themselves must be far more representative of the community at large." Similar sentiments were expressed in 1993 when it was also proposed that although the "independence of the judiciary must, of course, be sacrosanct," a Judicial Appointments and Training Commission would be established, and that judges should be selected from a larger pool "to ensure that all of the most able people are considered." 6 These are proposals which are widely supported. But how far should the process of reform go? What should be the goals and objectives of the reform process? And what are the appropriate democratic principles which should apply to the process of adjudication?

\section{The Judicial FUnCTION}

The first question which arises relates to the nature of the judicial function: it is only when we fully understand what it is that judges do that we can begin to determine the principles which should underpin the process of adjudication. As a starting point, we may readily conclude that the judicial role ought to be a limited one: it is not the job of the judicial branch to make the law, in the sense of laying down rules of general application which will apply to people other than the parties in a dispute before the courts. That is a legislative function for which the judicial process is wholly unsuited.? But unsuited or not, judges do exercise a clear legislative function, principally through the development of the common law. They also have an important role in determining the scope and application of laws made by other legislators (principally Parliament and local authorities). Moreover, judges are increasingly being given a de jure or de facto (depending on the jurisdiction) power of veto over the democratic process, as in Canada under the Charter, and in Britain under the Human Rights Act 1998. These different legislative functions raise important questions about the representativeness and accountability of those involved. Before exploring these questions, it is perhaps necessary to explain in greater detail why the judicial role is primarily a legislative one. Is this not a claim which stands condemned as a solecism?

$4 \quad$ Labour Party, Meet the Challenge, Make the Change: A New Agenda for Britain. Final Report of Labour's Policy Review for the 1990s (London: Labour Party, 1989) at 61 [hereinafter Meet the Challenge].

s Ibid.

- Labour Party, A New Agenda for Democracy: Labour's Proposals for Constitutional Reform (London: Labour Party, 1993), reproduced in R. Blackburn \& R. Plant, eds., Constitutional Reform: The Labour Government's Constituional Reform Agenda (Harlow: Addison Wesley Longman, 1999) at 46.

7 Litigation as a process of law-making focuses on a dispute between two parties, in which the issues are presented by two hired guns. The outcome is determined by a busy and overworked judge not only by careful reflection about where the public interest might lie, but also on the relative quality of the armoury before the court. The outcome of the dispute, the decision of the court, and consequently the precedent of general application established, may thus depend largely on what are in general terms extraneous factors such as the quality of arms available to the two sides, and the ability of each to purchase the best arms, or the highest paid "wage labourer": $K$. Marx \& F. Engels, "Manifesto of the Communist Party" in Selected Works, rev. ed. (Moscow: Progress Publishers, 1968) at 38. 


\section{A. Judges as Primary legislators: The Common law}

The first (and the most underestimated) legislative role of the courts is the common law itself, which determines the rules governing large areas of social and economic life: when we make a contract, if we are injured in an automobile accident, or if we make a will. This is a vast expanse of rule-making which remains completely untouched by the era of democracy, in the sense that the rules are made by a process from which the people are excluded, save only as litigants. For the most part, we are spectators with no right of participation in the development of the common law and consequently of the rules by which we are governed. Participation is instead confined to the advocates who appear before the court, a small cadre of self-appointed lawyers whose function it is to represent the self-interest of their client rather than the public interest of the community as a whole. But although he or she plays an important part in the drama, the advocate's is a supporting role: the decision-maker is the judge or judges, upon whom lies the responsibility to resolve the dispute. The law is made "in terms of what life has meant to those who make the law."8

It is perhaps inappropriate that law should be made in this way, and it is perhaps obvious that there should be no role for the common law proper in a properly functioning democracy. The common law is a process of law-making developed in a pre-democratic era, and maintained by a non-democratic form. All law, public or private, should be codified with a transparent democratic root. The democratization of the sources of law would not on its own remove the need for a properly functioning democratic theory and practice of adjudication. Those who apply legislation are not involved in a mechanistic or scientific process, but remain involved in a process of policy-making (albeit one of a qualitatively different nature) which is a secondary lawmaking function. But the fact that so much legislative power is delegated to the courts as legislators reinforces in a quite compelling way the need for a properly functioning democratic theory and practice of adjudication. If there are citizens among us who are to be endowed with a primary law-making function, they are placed in a position of power to determine how we all live our lives. As already suggested, those who exercise such power and authority over others must satisfy certain basic minimum democratic standards of representativeness and accountability. All the more so when the law is developed to reflect and promote contentious and contestable values. ${ }^{9}$

H.L. Laski, A Grammar of Politics, 4th ed. (London: George Allen \& Unwin, 1938) at 544.

It can hardly be pretended that the common law is in any way neutral, or that it is neutral in its application. As the historian Christopher Hill points out (C. Hill, Intellectual Origins of the English Revolution (Oxford: Clarendon Press, 1965) at 256), the common law is a product of the industrial revolution, developed to enable men of property to do as they wished with their own. The common law exists to preserve and promote economic liberty (see especially J. Lyons \& Sons v. Wilkins, [1896] 1 Ch. 811 (C.A.) at 826, Lindley L; Quinn v. Leathem, [1901] A.C. 495 (H.L.) at 534, Lord Lindley): not liberty per se, but economic liberty. There was no room in the common law's lexicon of liberty for political liberty, something to emerge much later as an afterthought. And by the same token, there is no room in the common law for equality, save in the most formal of sense. Little wonder then that those involved in this process - "the English judges" - should be traduced as being "ever complaisant in the services of the ruling classes" (Marx, Capital, (London: Lawrence \& Wishart, 1974) vol. 1 at 692). 
the right not to be subjected to slavery or forced labour (article 4). There is protection (in some detail) of the right to liberty (article 5), as well as the right to a fair trial (article 6), and protection from retrospective criminal legislation (article 7). Subsequent provisions deal with privacy; conscience and religion; expression; assembly and association; and marriage (articles 8-12). On top of this, the first protocol provides protection for private property (article 1), the freedom of parents to educate their children in accordance with their convictions (article 2), and fair and free elections (article 3). Some of these rights are unqualified. But some, on the other hand, may be subject to unspecified restrictions where these can be justified as being "necessary in a democratic society" on a number of grounds which include a number of predictable but variable considerations. ${ }^{19}$

Convention rights are thus wide-ranging, though there are a number of omissions. But unlike Canada, the British courts do not have the power to strike down legislation on the ground that it contravenes these rights; they may simply declare that the legislation is incompatible with them. Thereafter, it is for Parliament to decide how to respond. Although the legislation remains intact and applicable until amended or repealed by Parliament, in practice governments will be under great political pressure to introduce amending legislation to give effect to a declaration of this kind. The real power of the courts is in relation to public bodies such as ministers, government departments, the police, local authorities, and so on which will be required to comply with Convention rights in all that they do. This applies particularly when they exercise discretionary powers under legislation, or where they act under the authority of the common law, for example in the exercise of prerogative powers. For this purpose a public body is defined to include the courts and tribunals; in apparent contrast to the position in Canada ${ }^{20}$ it is thought that this means that the common law itself is to be developed and applied in a manner consistent with Convention rights ${ }^{21}$ though individuals can bring proceedings for a breach of the Act only against a public authority. ${ }^{22}$

\section{B. The HUMan Rights ACt 1998: The NATURE Of the Restraint}

These provisions give the courts two sources of power in the exercise of which they are to be guided but not bound by the jurisprudence of the European Court of Human Rights: i.e., the domestic courts are the masters of the international text in their own jurisdiction. ${ }^{23}$ The first power is the power to determine what the specific guarantees mean, not an insignificant power given the indeterminate nature of many of the rights provided. A good example is article 11 , which protects the right to freedom of association including the right to form and join trade unions for the protection of one's interests. But what does this mean? Does it mean that a trade union has a right to be

See Council of Europe, Committee of Ministers, European Convention on Human Rights (1950) arts. 8(2), 9(2), 10(2), 11(2), 12(2).

Retail, Wholesale and Department Store Union v. Dolphin Delivery (1986), 33 D.L.R. (4th) 174 (S.C.C.).

U.K., H.L., Parliamentary Debates, col. 783 (24 November 1997) (Lord Chancellor). Supra note 1 at ss. 6 and 7.

lbid. at s. 2. 
consulted by an employer, ${ }^{24}$ that a trade union has a right to be recognized by an employer for the purposes of collective bargaining, ${ }^{25}$ that the individual has a right not to have sanctions imposed upon him or her by his or her employer for taking part in a strike ${ }^{26}$ If not why not? Conversely, does the right to freedom of association imply a right not to associate, and if so why? If it does, is this a limited right not to associate, ${ }^{27}$ or an absolute right? ${ }^{28}$ And in answering these latter questions about nonassociation (in relation to which article 11 is deafeningly silent), how much weight (if any) should be attached to the traveaux preparatoires which make it clear that the freedom not to associate was expressly excluded? ${ }^{29}$

But the courts are not only empowered to determine the scope of the restraint on the democratic process or those who are accountable to it, they are also empowered to determine whether any violation of that restraint can be justified as being "necessary in a democratic society" on one of the permitted grounds. ${ }^{30}$ What this means in effect is that the courts must determine whether the outcome of the democratic process or the conduct of those who are democratically accountable is consistent with the objective principles of democracy. But of course there are no such principles. There are different conceptions of democracy (liberal democracy versus social democracy, for example), ${ }^{31}$ and different ways by which these different conceptions can be implemented (parliamentary versus presidential, for example). ${ }^{32}$ Yet here we have a regime which now says that the operation of "democracy" is to be constrained by a group of political actors empowered to impose their own vision of democracy on the community and to determine the boundaries within which the community should be governed. The fact that judges thus have the power to determine the very meaning of democracy makes it even more important that they themselves, institutionally, have been brought into the democratic age. Those who would presume to protect democracy from the democratic process should themselves satisfy basic democratic principles.

National Union of Belgian Police v. Belgium (1979-80), I E.H.R.R. 578 (Eur. Ct. H.R.). Swedish Engine Drivers' Union v. Sweden (1979-80), 1 E.H.R.R. 617 (Eur. Ct. H.R.). Schmidt and Dahlstrom v. Sweden (1979-80), 1 E.H.R.R. 632 (Eur. Ct. H.R.). Young, James and Webster v. United Kingdom (1982), 4 E.H.R.R. 38 (Eur. Ct. H.R.) [hereinafter Young]. Sigurjonsson v. Iceland (1993), 16 E.H.R.R. 462 (Eur. Ct. H.R.).

Young, supra note 27 at 53.

These vary from article to article, but in the case of article 11 are quite extensive, permitting restrictions in the interests of national security or public safety, for the prevention of disorder or crime, for the protection of health or morals, or for the protection of the rights and freedoms of others. It also allows restrictions on members of the armed forces, the police, and those engaged in the administration of the State. Article 10 (freedom of expression) is in some respects more extensive.

On this see K.D. Ewing, "Human Rights, Social Democracy and Constitutional Reform" in C. Gearty \& A. Tomkins, eds., Understanding Human Rights (London: Mansell, 1996) 40.

For an account of how the European Court of Human Rights approaches this issue, see Young, supra note 27. 


\section{AN (UN)REPRESENTATIVE JUDICIARY}

Turning then from the question of what the judges do, to a consideration of the principles which should determine who the judges should be, the first requirement of any institution which exercises legislative power is that it should be representative of those on behalf of whom it exercises that power. ${ }^{33}$ The normal method of securing that a political institution is representative in this way is by a process of election. It is not clear why a representative judiciary should not be elected. ${ }^{34}$ The typical argument against it is that judges would respond in a populist way in the discharge of their duties. However, this is a difficult argument for a democrat to run with. It is tantamount to saying that we cannot have elections because the judges might respond to the views of those who elect them, or the views which they promised to uphold. But if the idea of election is a walk on the wild side, there is a weaker sense in which the concept of representation might be used. It may not be desirable for judges to directly represent the community, but there is no reason why they cannot be representative of the community, in terms of obvious considerations such as race and gender, and in terms also of social background, so that a judicial career is open, in principle and in practice, to all who are suitably qualified. This has long been a concern in relation to the magistracy, ${ }^{35}$ though curiously not in relation to the superior courts. ${ }^{36}$

\section{A. THE BRITISH EXPERIENCE}

At the present time, it would be impossible to say that the judges in Britain are in any sense representative of the community, on any ground on which one might settle as an appropriate yardstick. ${ }^{37}$ Take gender, for example. It should not be necessary to rehearse the arguments in favour of an equal gender balance. ${ }^{38}$ Yet, at the time of writing, there are no women members of the Judicial Committee of the House of Lords. Are we to conclude that there is not, and never has been, any woman in Britain good enough to sit in her Supreme Court? Other countries have been able to accommodate at least the token woman, and women have broken the juristocratic glass ceiling in

For a different conception of how the judges might be said to represent the community, see F.C. DeCoste, "The Separation of State Powers in Liberal Polity: Vriend v. Alberta" (1999) 44 McGill L.J. 231. Here DeCoste emphasizes the representative role in terms of judicial function. The following section concentrates on the complementary question of personnel.

See R. Miliband, Socialism for a Sceptical Age (London: Polity Press, 1994) at 76-77.

See Labour Party Annual Report 1922 (London: Labour Party, 1922) at 238; Labour Party Annual Report 1930 (London: Labour Party, 1930) at 170; Labour Party Annual Report 1931 (London: Labour Party, 1931) at 50; Labour Party Annual Report 1932 (London: Labour Party, 1932) at 259; Labour Party Annual Report 1933 (London: Labour Party, 1933) at 23.

The corresponding concern was to discourage people from using the ordinary courts: see Labour Party Annual Report 1922, ibid. Trade union members at the time were prevented by legislation (Trade Union Act 187I, (U.K.), 34-35 Vict., c. 31) from suing their unions in the ordinary courts, though the courts managed to find ways round this. See C. Grunfield, Modern Trade Union Law (London: Sweet \& Maxwell, 1966), at 72-92. of the judiciary to reflect particular sections of the community": HC 52-1I (1995-96), para. 36. See especially, B. Wilson, "Will Women Judges Really Make a Difference?" (1990) 28 Osgoode Hall L.J. 507. 
Australia, Canada, and the U.S. But not in Britain. Only quality counts, regardless of gender. The position is not much better in the Court of Appeal and the High Court; at the time of writing only 1 of the 35 Court of Appeal judges is a woman (Lord Justice Butler Sloss), ${ }^{39}$ and only 8 of the 98 High Court judges are women. The Court of Appeal typically supplies the House of Lords, just as the High Court typically supplies the Court of Appeal. ${ }^{40}$ But if gender is bad, race is even worse. There are no black or Asian members of the High Court, Court of Appeal, or House of Lords. The Bench in fact is remarkable for its homogeneity: apart from being exclusively male and white at the highest level, it is also almost exclusively Oxbridge in education and training. ${ }^{41}$

This lamentable state of affairs is thought to be a reflection of two related problems. The first concerns eligibility for appointment to the Bench. At the time of writing, appointment is principally from the ranks of the Bar, that is to say, practising barristers. ${ }^{42}$ The pool is thus extremely small, and difficult to penetrate. Although there are no comprehensive research data, a good working hypothesis is that members of the Bar would be disproportionately male, disproportionately white, and disproportionately middle class in origin. Indeed, it is only since 1990 that the Sex Discrimination Act $1975^{43}$ and the Race Relations Act $1976^{44}$ have applied to practice at the $\mathrm{Bar},{ }^{45}$ and it has required litigation to establish that barristers' pupils are entitled to be paid the statutory minimum wage. ${ }^{46}$ Not unrelated to this is the "system" of appointment, if it can be dignified in these terms. The arrangements in place at the time of writing read like an episode from a Dickens novel. The appointment of judges by the Lord Chancellor at the highest level is based on a system of "soundings" of other judges and senior members of the Bar, a process which is supposed to ensure that only "sound" people are appointed. ${ }^{47}$ It is thus not an open selection system based on advertising (though High Court vacancies are now advertised), objective criteria, assessments, interviews and references, as is the common currency of most other forms of employment. ${ }^{48}$ Unsurprisingly, these arrangements have been strongly criticized.

On the masculinization of women judges, see K.D. Ewing, “The Bill of Rights Debate: Democracy or Juristocracy in Britain?" in K.D. Ewing, C.A. Gearty \& B.A. Hepple, eds., Human Rights and Labour Law: Essays for Paul O'Higgins (London: Mansell, 1994) 174.

These figures are drawn from F. Gibb, "Is this the end of 'secret soundings'?" The Times Law Supplement (5 October 1999) 3.

See J.A.G. Griffith, The Politics of the Judiciary, 5th ed. (London: Fontana Press, 1997) at 18-21. Since the Courts and Legal Services Act 1990, (U.K.), 1990, c. 41, it has been possible for solicitors to be eligible for appointment: at the time of writing only one member of the High Court was a solicitor; none has made it to the Court of Appeal or the House of Lords.

(U.K.), 1975, c. 65.

(U.K.), 1976, c. 74.

Supra note 42, s. 64.

Edmunds v. Lawson Q.C., [2000] I.R.L.R. 18 (E.A.T.).

Under this system, the Bench effectively reproduces itself, by people in the image of those who are sounded. As a result it is likely to perpetuate the values of a white male Oxbridge elite, divorced from the reality of modern of everyday life, in the same way as the predecessors of the current Bench stood equally condemned.

As pointed out by Gibb, supra note 40 . 
VoL. $38(3) 2000$

\section{B. The Peach Report}

Sensitivity about the judicial appointments procedure led the Lord Chancellor to appoint Sir Leonard Peach in 1999 to report and advise on a number of aspects relating to judicial appointments. ${ }^{49}$ Peach was asked to advise on three principal matters: the appropriateness of the criteria and the procedures for selecting the best candidates, the extent to which candidates are assessed objectively against the criteria for appointment, and the existence of safeguards in the procedures against discrimination on the grounds of race or gender. On each of these questions, Peach seemed broadly satisfied with the current arrangements. True, a number of changes were proposed but these were mainly to consolidate and formalize the procedures and to introduce, through a Judicial Appointments Commission, a degree of external scrutiny of the way in which the procedures operate in practice. But it is important to emphasize that the Judicial Appointments Commission (of up to ten people, no more than a third of whom are to have a legal background) would not make the appointments or even recommend the appointments. The Commission, rather, would be "concerned with the ongoing audit of the processes and policies for making and renewing judicial appointments, for handling grievances and appeals resulting from the application of these processes/policies, and for recommending improvements and changes to the Lord Chancellor." 50

Peach also seemed broadly satisfied that the existing criteria were appropriate, certainly for appointment at the highest level, though this is not to diminish the importance of some of his recommendations. But his is not a document which will lead to a radical change in terms of producing a Bench which is more representative of the community it serves. There is admittedly some thoughtful consideration of the question of gender and racial representation, based largely on the 42 recommendations in a draft report by a joint working party on equal opportunities issues, many of whose recommendations Sir Leonard supported while noting that several of the recommendations reflected current practice. The joint working party's recommendations were wide-ranging, dealing with: (i) the principle where part-time service is a prerequisite to full-time appointment; (ii) the appointment of employers employed in the public service; (iii) positive action by the Lord Chancellor's Department to give practical assistance to under-represented groups "who have the requisite ability and talent"sl; (iv) changes to the application and selection procedures; and (v) the introduction of an appeals mechanism together with better appraisal and evaluation procedures. Although valuable, it is likely to be some time before these recommendations lead to any significant changes at the highest levels.

See Sir L. Peach, "An Independent Scrutiny of the Appointment Processes of Judges and Queen's Counsel in England and Wales: A Report to the Lord Chancellor by Sir Leonard Peach" (London: HMSO, 1999)(The Peach Report), online: <http://www.open.gov.uk/cd/judicial/peach/report.htm.> (date accessed: 9 August 2000). 


\section{A Representative Judiciary: Options for Change}

It is clear that the Peach report does not have the answers to the question of the representativeness of the Bench. In fairness, it was probably not expected to. There are in fact two interconnected problems standing in the way of a representative Bench: one is the method by which people are recruited and the other is the pool of people who are eligible to be recruited. Reform of the former is important, but it will make little significant difference without a corresponding reform of the latter. The case for a representative judiciary thus suggests the need for a system of appointment and recruitment which opens up participation in the judicial branch to all qualified citizens. If judges make the law by which we are all governed, then all who are qualified have a legitimate expectation of taking part in that process if they have the ambition to do so. It is not a form of political participation which should depend on the exercise of various forms of patronage: that of the admissions tutors of particular universities (public institutions which still recruit half their students from the private education sector); that of barristers who decide whom to admit to their chambers as pupils and tenants; and that of the Lord Chancellor who, on the advice of the other judges, decides on appointments. If the Bench is to be made more representative, the pool of eligible candidates needs to be significantly expanded.

\section{A. Reforming the Procedures}

A minimalist response would be to reform the current arrangements. One possibility would be to enlarge the pool of people eligible for appointment by extending it to include lawyers other than barristers, notably solicitors as well as academics. There are many more solicitors than barristers. Although solicitors are now in principle eligible, in practice, only one has made it to the High Court; none have made it to the Court of Appeal or above. The Law Society (the body representing solicitors) in particular is strongly critical of the current procedures. Although High Court positions are now advertised, there are no interviews. Decisions are made by the Lord Chancellor who "reviews suitable candidates at a meeting with the Lord Chief Justice, other Heads of Division, the Senior presiding Judge, the Vice President of the Queen's Bench Division and the Vice President of the Court of Appeal, taking into account the nature of the expertise and experience required."52 It is not clear how many solicitors have applied, but it would appear to follow from the concerns of the Law Society that solicitors would stand a better chance of being appointed if this process, based on "soundings" or consultation with unnamed and unknown others, were to be scrapped and replaced with modern selection procedures. Although these measures might represent an important step forward, it would be a small and incomplete step.

Under arrangements of this kind, candidates for the Bench would still have three hurdles to clear: they would have to secure appointment as legal practitioners; they would then have to succeed in the practice of law (in whichever branch of a divided profession); and they would then have to secure appointment as a judge, by whatever system is in place. It is by no means clear why participation in a private labour market 
should be a qualification for appointment at all, or indeed how its minimalist reform will secure a more representative Bench. It may deal with questions of gender. ${ }^{53}$ But that would not make the Bench more representative on other grounds. Access would remain confined (except for the token academic) to successful practitioners, that is to say, to people who spend their lives in the service of wealthy clients, imbued with the values and enriched with the money of wealthy clients. Whatever else this may do, it is by no means guaranteed to produce a Bench representative (or even more representative than is currently the case) of the community. More radical action is called for. There is a need to learn from the experience of other systems, beyond the common law, where judicial appointments are handled differently. The limitations of the minimalist response point clearly in the direction of a career judiciary open to all at the point of graduation.

\section{B. Transforming the Procedures}

In Italy, as in other countries, graduates may choose a judicial career, perhaps an unusual arrangement for those of us schooled in the common law. There, graduates enter the magistracy as a career, having sat and passed the entrance examinations. Entrants must be over 21 but younger than 40 . Once in the system they move automatically through the various stages - Tribunale, corte d'appello, and Cassazione - as they become more experienced. ${ }^{54}$ The procedures for the appointment at the highest level, the Corte Costituzionelle, are very different, though senior judges are responsible for appointing one third of its fifteen members (another third being nominated by the legislature, and another by the President). ${ }^{55}$ But how could a career judiciary work in a common law system like the UK? It would be perfectly possible for people to be recruited from Law School and to undergo an additional form of training as Judicial Officers. Access would be possible at any time to anyone suitably qualified. It would thus be open to graduates to choose a judicial career, just as they currently choose a career at the Bar or as a solicitor. Access would be open to Oxbridge graduates; but it would be open to others as well. It is easy to manage a staged career path, given the plethora of administrative tribunals and courts which now exist in the United Kingdom.

It would be possible to anticipate a career path through different levels of adjudication as the judge became more experienced in the art of adjudication. People would serve in the highest courts because of their skill as adjudicators, not because they had proved successful as representing the interests of private clients or because they had revealed particular courtroom skills. In other words, they would be chosen because they had relevant experience for the job. And, more importantly, they would be chosen by a more transparent and inclusive system, which from the point of entry would be better

Though even this is seriously open to question in view of the fact that "women still account for only 17 percent of the partners in the country's main law firms": C. Digby-Bell, "Why women face a bar in legal firms," The Times Law Supplement (19 October 1999) 6. Women still represent only one third of the solicitors practicing in England and Wales (ibid.). 
able to promote gender and racial equality. By helping to break the chain of Oxbridge, then Bar, then Bench, it would also raise the possibility of a more socially diverse Bench. A system based on public appointment in this way provides greater opportunities for access to a wider range of people who appear currently not to be represented in the system, certainly at its highest levels. The real challenge in promoting a more representative Bench would be one of equality of access to Law School, equality of educational experience at Law School, and equality of recognition of educational achievement at Law School.

\section{AN (UN)ACCOUNTABLE JUDICIARY}

The judicial role calls not only for a representative Bench. Those who perform a legislative role must also be accountable for the way in which that role is performed. If we eschew the idea of the election of judges, judicial accountability cannot mean that judges are accountable to the people in the same way that members of Parliament are, that is to say, that they must submit themselves to re-election on a regular basis and enable the people to judge them by their record in office. But it does not follow from this that there are not other means of accountability. Ministers of the Crown, for example, are accountable not only in the sense that they must submit themselves and their record in office to the people on a regular basis but also in the sense that they are accountable to Parliament (the people's representatives) for the manner in which they discharge the responsibilities of office.$^{56}$ Indeed ministers are collectively responsible to Parliament for their handling of the nation's affairs and remain in government collectively only so long as they retain the confidence of the House of Commons. So the concept of political accountability comes in different forms, with different forms being appropriate for different institutions within different constitutional traditions. But so far as the judges are concerned, in the Westminster system of government, there are perhaps two ways in which the concept of accountability is appropriate.

\section{A. THE BRITISH EXPERIENCE}

In the first place, there is the accountability of the judge as legislator. Who are these judges? When they are appointed, we know nothing about them, apart from what may be recorded in their Who's Who entry. The issue of accountability of the judge as legislator in turn raises two questions: one relates to appointment, and another to the discharge of duties. As far as the former is concerned, we should keep in mind that judges are being appointed to make law of general application. They are legislators, however much the naive may protest otherwise. Those who assume political office should expect to be subjected to some form of public scrutiny about (i) why they want the office, (ii) what qualities of competence they will bring to the office, and (iii) more importantly, what political values they will bring to the office. We would never dream of electing a member of Parliament without having some knowledge of the Party he or she represents or the values and baggage that he or she will bring with him or her. Why then do we do just that in the case of judges whose influence over the way we live may 
be greater than the member for Midlothian? There is a strong and compelling case to require judges at the point of promotion and recruitment to expose themselves in this way to the people's representatives, before a Select Committee of the House of Commons sitting in public.

However, there is another dimension to the concept of accountability of the judge as legislator. It is not a static concept, the conditions of which are met once the judge is appointed. On the contrary, it is a continuing obligation, a reality fully exposed by the Pinochet case. ${ }^{57}$ It is true that judges are expected not to play an active role in the work of political parties. ${ }^{58}$ But it appears that they are not required to divest themselves of other political, economic, or social interests. In the Pinochet case, it will be recalled, one member of the House of Lords, Lord Hoffman, acted very foolishly by failing to disclose his relationship with Amnesty International, an organization which had intervened in the case. The information only came to light after the House of Lords had decided that Pinochet was not immune from criminal proceedings for torture. ${ }^{59}$ The whole affair raises questions about whether there should be for judges a mandatory Register of Interests, as there is for members of Parliament. ${ }^{60}$ This requires MPs to list various interests in order to ensure that people are fully informed of the causes they may be likely to promote while in office. It does not follow that the same categories of registrable interests would be appropriate for judges: there should be no need to register remunerated employment by judges. But there is no reason why the principle should not apply with appropriate modifications.

\section{B. The locaball Case}

The accountability of the judiciary as a legislative institution thus requires a greater degree of transparency, both at the time of appointment and as a continuing obligation. This would have helpful implications for the other question of accountability, namely, the accountability of the judge as an adjudicator. One way in which this accountability is discharged is by means of the rule against bias, whereby the judge is expected not to have an interest in the dispute with which he or she is confronted. As was recently pointed out by the Court of Appeal in Locabail (U.K.) v. Bayfield Properties, ${ }^{61}$ this interest may arise in one of two ways. First, there are cases where "bias is effectively presumed," and where the judge may be automatically disqualified because of a financial or other direct interest in the outcome of the dispute. Even then the disqualification may be waived, and it is now no longer accepted that "any direct pecuniary interest, however small" disqualifies. But how are the parties to know whether a judge has a disqualifying interest if the judge is not questioned about his

R. v. Bow Street Metropolitan Stipendiary Magistrate, ex parte Pinochet Ugarte (No.2), [1999] 1 All E.R. 577 (H.L.).

A.W. Bradley \& K.D. Ewing, Constitutional and Administrative Law, 12th ed. New York: Addison Wesley Longman, 1997) at 23 (the case of Lord Avonside and the Conservative Party). R. v. Bow Street Metropolitan Stipendiary Magistrate, ex parte Pinochet Ugarte (No.l), [1998] 4 All E.R. 897 (H.L.).

U.K., H.C., The Code of Conduct together with The Guide to the Rules Relating to the Conduct of Members (London: HMSO, 1996) [hereinafter Code of Conduct].

[2000] 1 All E.R. 65 (C.A.). 
finances or his interests at the time of appointment and if the information is not updated? At the present time, it is left to the judge himself or herself to disclose any such interest to the parties; a failure to do this may lead to a decision being challenged after the event. But that can be done only if the information becomes known. ${ }^{62}$

Apart from automatic disqualification, there are cases where a judge may be disqualified as a result of an examination of all the facts and circumstances, if an appeal court concludes that there was "a real danger (or possibility) of bias." ${ }^{63}$ In the Locabail case, the court declined to list the factors which may or may not give rise to a real danger of bias, though it was unable to

conceive of circumstances in which an objection could be soundly based on the religion, ethnic or national origin, gender, age, class, means or sexual orientation of the judge. Nor at any rate ordinarily, could an objection be soundly based on the judge's social or educational or service or employment background or history, nor that of any member of the judge's family; or previous political associations; or membership of social or sporting or charitable bodies; or Masonic associations; or previous judicial decisions; or extra-curricular utterances (whether in textbooks, lectures, speeches, articles, interviews, reports or responses to consultation papers); [and so on]. ${ }^{\text {.4 }}$

Given that there remain some disqualifying interests, and given the presence of circumstances other than the ordinary, the question again arises: How are litigants expected to know about the bias of the judge or the factors which may give rise to a real danger of bias if the judge is never examined on his interest and if they are concealed from the public?

\section{AN ACCOUNTABle Judiciary: OPTIONS for Change}

There is thus a strong case for enhancing accountability by transparency, as a means of increasing the accountability of the judge both as a legislator and as an adjudicator. But this by no means exhausts the legitimate claims for judicial accountability that a community may have. There is also the question of the performance of the judge as legislator and as adjudicator; judges should be expected to account for the way in which they discharge their responsibilities. At the present time, there is precious little scope for accountability of this kind. The judge who makes a crass remark may be reprimanded by the Lord Chancellor. ${ }^{65}$ So what? The judge who gets it "wrong" in

In any other walk of life that would be wholly unacceptable: it is certainly not tolerated on the part of MPs. See Code of Conduct, supra note 60.

63 Supra note 61 at 73.

ot Ibid. at 77. The so on refers to "previous receipt of instructions to act for or against any party, solicitor or advocate engaged in a case before him; or membership of the same Inn, circuit, local Law Society or chambers" (ibid).

os At the time of writing, five judges have been reprimanded by the Lord Chancellor since 1 May 1997 "for making unacceptable racial comments": S. Clough, "Judge attacks Irvine's politically correct rules on race," Daily Telegraph (1 October 1999). One of these involved a joke made by a judge at a legal dinner. A revised guide for judges on how to avoid any perception of racial bias or insensitivity was attacked by one retiring judge as "political corrections in all its horrid forms" (ibid). 
a particular case can be the subject of appeal and may be overruled. Although obviously important, this is a form of scrutiny internal to the system itself; it offers no external scrutiny and certainly no external scrutiny of the ultimate court of appeal. Admittedly, there is the possibility of public criticism in the press, the existence of which is extremely important, or indeed criticism in the law reviews as the ultimate and most penetrating form of censure. But the former speak for the proprietors (and have no democratic legitimacy), while no one reads the self appointed critics in the latter and fewer still (rightly) take them seriously.

\section{A. VoluntaRY AND SElective SCRUTinY}

Reference to the law reviews raises another question about accountability through scrutiny. It is the growing vogue for judges to submit, and journal editors to accept, articles on a wide range of legal questions. At the present time, we are treated to a process of what is in effect voluntary and selective accountability by some judges, writing in a wide range of magazines, both general and specialist. The favoured journals over the last five to ten years appear to be the Law Quarterly Review and Public Law, though in truth there are few journals which do not contain a sprinkling of judicial essays, presumably to give confidence and credibility (from the Modern Law Review to the Cambridge Law Journal to the Liverpool Law Review to the King's College Law Journal to the Law Teacher). Some judges are more active than others in wishing to project themselves on others; the Lord Chancellor is a productive author, as are Lord Browne Wilkinson, Sir John Laws, Sir Peter Millett, Sir Stephen Sedley, and Lord Woolf of Barnes. But a survey of just three journals (Law Quarterly Review, Public Law, and European Human Rights Law Review) unearths contributions from Dame Mary Arden, Sir Thomas Bingham, Lord Justice Simon Brown, Sir Robert Carnwath, Sir Robin Cooke, Sir Anthony Hooper, Lord Hope of Craighead, Lord Roskill, Richard Scott, Lord Steyn, and Sir Robert Walker.

But it is not only British judges who put pen to paper or finger to keyboard in this way. The journals are adorned by the contributions of senior judges from Australia, Canada, New Zealand, and the U.S. Conversely, English judges travel far and wide, and their views have been impressed upon the peoples of Australia, Canada, and the United states through vehicles such as the University of Western Australia Law Review, the Osgoode Hall Law Journal, and the Texas International Law Review. The subject matter of these and the articles referred to in the previous paragraph vary enormously, from vigorous support for highly partisan and politically contentious campaigns (such as the campaign for the incorporation of the European Convention on Human Rights before the Human Rights Act) ${ }^{66}$; to the consideration of (sometimes controversial) problems arising in a particular area of law and practice (sometimes with suggestions as to how these might best be overcome); ${ }^{67}$ to the consideration of a particular case 109 L.Q.R. 390.

67 Lord Justice Simon Brown, "Public Interest Immunity" [1994] P.L. 579; Sir P. Millett, "Restitution and Constructive Trusts" (1998) 114 L.Q.R. 399; Lord Steyn, "Contract Law: Fulfilling the Reasonable Expectations of the Honest Men" [1997] 113 L.Q.R. 433; Sir H. Woolf, "Judicial 
in which the judge may have taken part. A good example of the latter is the article by Sir Konrad Schiemann on the much criticized Rose Theatre Trust case, ${ }^{68}$ in which he refused to grant standing in judicial review proceedings, in circumstances which seemed to run against the grain of recent developments in administrative law. ${ }^{69}$

\section{B. MANDATORY AND UNIVERSAL SCRUTINY}

These literary judicial forays appear to be greatly welcomed by magazine publishers, editors, and readers. Otherwise they would not be published. But why should the accountability of judges be partial and selective? And why should it be on terms determined by the judges themselves? If judges are prepared to publicize their views in this way, why not directly before a body representing the people in a public forum, such as a Select Committee of the House of Commons? Quite simply, if ministers and civil servants can be called before a Select Committee to account to the representatives of the people for the handling of the nation's affairs, why should not judges be subject to a similar obligation? It has already been suggested that, in the interest of transparency, senior judges could be required to appear before a Select Committee before their appointments. But there would be a case for saying that senior judges could be recalled (or invited if the notion of a recall would upset those of nervous disposition) to appear before a Select Committee in the interests of a greater scrutiny of just what it is the judges do. It is difficult to see what possible objection there could be to this in principle (depending of course on what it is the judges would be asked to do). The Law Lords already take part in parliamentary proceedings, a role recently endorsed by the Royal Commission on House of Lords Reform. ${ }^{70}$

The appearance of judges before a Select Committee could serve a number of purposes, not the least of which is that the judges would have a larger platform and a more substantial forum than could ever be provided by the Law Reviews for the expression of their opinions. But more importantly, it would provide an opportunity for the public through their elected representatives to engage with a process of law making from which they are currently excluded. It should perhaps be made clear that scrutiny by Select Committee should not be designed to censure the judge who makes an offensive racist remarks; to cross-examine the judge who willfully ignores the clear intention of Parliament when interpreting a statute; or to criticize the judge who fails to disclose an interest in a particular case. These matters are already taken care of by the system as it presently works. The purpose of this form of scrutiny rather is to promote a form of dialogue between people's representatives and appointed judges about major legal developments, to help the governed to understand what is happening and why; and to provide an opportunity to the governors to explain and justify. A good example of where this could usefully have been done is in relation to judicial review

Review: A Possible Programme for Reform" [1992] P.L. 221.

$R$ v. Secretary of State for the Environment, ex parte Rose Theatre Trust Co. (1900), 1 Q.B. 504 (H.L.).

Sir K. Schiemann, "Locus Standi" [1990] P.L. 342.

U.K., Royal Commission on the Reform of the House of Lords, $A$ House for the Future, Cmnd 4534 (London: Stationery Office, 2000) c. 9 [hereinafter $A$ House for the Future]. 
of administrative action which has developed very quickly without any input from the people's representatives, and without any opportunity for the judges to provide a coherent account of the process.

\section{AN INDEPENDENT JUDICIARY}

One of the likely concerns about arguments for a more representative and accountable Bench is the implications which any proposals may have for the independence of the judiciary. For some, of course, the independence of the judges is a "sham," which "but serve[s] to masks their abject subserviency to all succeeding governments."" So like all other public servants, "magistrates and judges" should be "elective, responsible and revocable." democratic or socialist forms of government, is a concept which is of critical importance ${ }^{73}$ : "it is integral to ... the mechanism of political responsibility that every state should possess a vigorous and independent judiciary." 74 Without an independent judiciary, there can be no rule of law, itself a concept fundamental to any regime, liberal or socialist, which lays any claim to be democratic. ${ }^{75}$ Judges should be representative of, and ultimately accountable to, the people, not to the government of the day. Independence comes in a number of guises; there is the question of independence from the parties in the dispute; there is the question of independence from the government of the day; and there is independence from a set of dominant political values. But far from undermining the independence of the judiciary in these forms, robust accountability procedures would serve only to promote and protect it.

\section{A. THE BRITISH EXPERIENCE}

So far as the first two of these aspects are concerned, judicial independence is secured in a number of ways. One is by the principle of nemo judex in rem suam (no one should be a judge in his own cause) which disqualifies a judge from sitting if he or she has an interest in the case through a social, economic, or political relationship with one of the parties to the dispute. This was the issue in the Pinochet case where Lord Hoffman was disqualified because of his personal links with one of the

"A notion which some judges seem to be anxious to encourage.

72 K. Marx, "The Civil War in France," in K. Marx \& F. Engels, Selected Works, supra note 7 at 291-92.

73 Even if it is difficult to achieve, a point acknowledged by Scrutton L.J.'s disarmingly frank observation to the London law students, published in 1923, when he said that "[t]he habits you are trained in, the people with whom you mix, lead to your having a certain class of ideas of such a nature that, when you have to deal with other ideas, you do not give as sound and accurate judgments as you would wish. This is one of the great difficulties at present with Labour. Labour says 'Where are your impartial Judges? They all move in the same circle as the employers, and they are all educated and nursed in the same idea as the employers. How can a labour man or a trade unionist get impartial justice?' It is very difficult sometimes to be sure that you have put yourself into a thoroughly impartial position between two disputants, one of your class and one not of your class." (Scrutton, "The Work of the Commercial Court" (1923) I C.L.J. 1 at 8).

$74 \quad$ Supra note 8 at 85.

75 See C. Sypnowich, The Concept of Socialist Law (Oxford: Clarendon Press, 1990) at c. 3. 
intervenors in the case. ${ }^{76}$ Another way by which independence is secured is by virtue of the fact that by convention judges are expected to relinquish any formal interest in a political party (including most obviously the governing party), and also by virtue of the fact that judges are by convention protected from criticism (far less pressure) by members of the government. ${ }^{77}$ Judges are also protected from criticism by members of Parliament, save on a substantive motion. ${ }^{78}$ Also, of course, judges have security of tenure and may not be dismissed for their performance in any particular case. Indeed, senior judges may only be removed following an address by both Houses of Parliament, ${ }^{79}$ a procedure which has never been invoked in modern times. ${ }^{80}$

So far as the third of these foregoing meanings of independence is concerned, judges have a remarkable degree of autonomy to develop the common law in a way which reflects a certain ideological position. There is no such thing as ideological neutrality and there is no pretence of ideological neutrality in the approach of the courts to common law questions. This ideological autonomy in the development of the common law is reflected in the values which the courts bring to the interpretation of statutes. A classic example of this is Express Newspapers v. MacShane, ${ }^{81}$ concerning the interpretation of the Trade Union and Labour Relations Act $1974^{82}$ which was designed to give a statutory immunity from tortious liability to create a right to strike. Despite the social objective of the legislation, the immunity was said by Lord Diplock to "stick in the gorge of anyone trained in the common law." ${ }^{33}$ This ideological autonomy also allows the courts to develop common law principles based on private law principles (derived from the law of trusts) to subvert the democratic process. So in a number of particularly well-known cases, the courts have held that elected local authorities may not pay fair wages to their staff, pay women the same rate as men, ${ }^{84}$ subsidize the public transport of elderly citizens, ${ }^{85}$ or subsidize the London underground..$^{86}$

\section{B. JUdicial INDEPENDENCE AND JUdicial ACCOUNTABILITY}

It is difficult to see how these forms of judicial independence would be undermined by greater judicial accountability. As far as the question of independence of the parties is concerned, this would be strengthened by a Register of Judicial Interests which everyone could consult, and which would provide a full record of the commercial and

Supra note 57.

Bradley \& Ewing, supra note 58 at c. 18.

E. May, Treatise on the Law, Privileges, Proceedings and Usage of Parliamentary, 22d ed. by Sir D. Limon \& W.R. McKay (London: Butterworths, 1997).

Supreme Court Act 198I, (U.K.), 1981, c. 54, s. 11(3).

Though two Scottish sheriffs have been removed from office. See Stewart v. Secretary of State for Scotland (1995), S.L.T. 895 (Outer House).

[1980] 1.C.R. 42 (H.L.) [hereinafter Express Newspapers].

(U.K.), 1974, c. 52.

Express Newspapers, supra note 81 at 57.

Roberts v. Hopwood, supra note 3.

Prescolt v. Birmingham Corporation, [1955] Ch. 210 (C.A.).

Bromley $L B C$ v. GLC, [1983] 1 A.C. 768 (H.L.). Despite in the last case having a clear electoral mandate to do so. 
interests of individual judges. By doing so, it would not only preserve public confidence in the judicial process, it would also enable the parties to be confident that the court was truly independent. It is not easy to see how transparency would undermine independence. Nor is it easy to see why accountability in the form of dialogue with a parliamentary committee would undermine independence. What is this likely to produce? Perhaps a greater awareness on the part of the public through their elected representatives of the reasons for any developments in the law? Perhaps a greater awareness on the part of judges of the public response to these developments and of their implications? Perhaps an opportunity for the public to have a voice albeit remotely and indirectly - in the development of areas of rule-making from which they are wholly excluded? The concern is that it would go further. It might lead parliamentarians to express surprise or even criticism of judicial developments or decisions, particularly where judges exercise their power in a controversial manner.

But so what? Why should judges alone of the bearers of political power be protected from sustained scrutiny? Such scrutiny becomes all the more important when we reflect upon the ideological values of the common law and the judicial process generally. Judicial independence means judicial immunity: it means that these values are never publicly exposed, that they are never discussed in a public forum (except one dominated by lawyers), and that they are never tested and challenged by the values of contemporary society. (It is true that the common law is not static, and that movement can be detected - not only in decisions but in the values which underpin these decisions. Yet progress is slow, though even here there is no accountability of the judges for the fact that they have picked up new values and developed new concepts to reflect their view of changing social conditions and expectations. ${ }^{87}$ ) The question arises again: why should judges not have to account for the ideological underpinnings of the values which they develop and apply? The possibility that they might be held to account in this way may also lead judges in the direction of a greater degree of ideological plurality. If this is to be seen as a loss of independence, then it is a loss which is well worth contemplating.

\section{AN INDEPENDENT JUdiciary: OPTIONS fOR Change}

There is thus no reason to believe that measures designed to promote a more representative and accountable judiciary would undermine the independence of the judiciary. This is not to say that the independence of the judiciary is unimportant, or that there are not measures that could be taken to reinforce the principle. But it does not follow that steps to enhance judicial independence will necessarily make the Bench more (or less) representative and accountable, any more than steps to make the Bench representative and accountable would make it (more or) less independent. So far as enhancing judicial independence is concerned, there are currently two items to be dealt with. The first relates to the manner of appointment of judges. As already pointed out, judges are political appointments in the sense that they are appointed by the Lord

The House of Lords has, for example, decided that employers owe their employees a duty of mutual trust and confidence: Malik v. BCCl, [1998] A.C. 20 (H.L.). Great idea. But why? And what are the implications? 
Chancellor, who is a government minister; ${ }^{88}$ judges are thus executive appointments. ${ }^{89}$ The second concern relates to the fact that in the British system the highest court of appeal in England and Wales is the House of Lords. This means that the highest court is located in the nation's Parliament. Some see this as anachronistic, and it gives rise to serious questions about the extent to which the judges are institutionally independent, to say nothing of the extent to which the separation of powers is respected in the British system of government.

\section{A. A Judicial APpointments Commission}

As we have seen, there has been some concern that it is desireable to "take decisions on the appointment of judges out of the direct control of politicians." 90 Although there is no suggestion at the present time of judicial appointments being made for political reasons, it is certainly the case that political appointments have been made in the past. Two examples are: first, appointments to the House of Lords in the early years of the 20th century designed to ensure a Liberal balance; ${ }^{91}$ and second, the convention that the incumbent Attorney General (who may well previously have held other political offices, as in the case of Sir Gordon Hewart) would succeed when the position of Lord Chief Justice became vacant. ${ }^{92}$ As for more recent judicial appointments, we can only speculate. One possible response to this legacy, and to fears that it may be repeated in the future, is the creation of a Judicial Appointments Commission, which would be an independent public body responsible for appointments; this proposal enjoys wide support on the "radical" centre. But this would be a different animal from that proposed by the Peach Report (at least in terms of its functions if not its composition). ${ }^{93}$ Such a Commission would have responsibility not only for monitoring appointments in

The Lord Chancellor in fact occupies a unique position: he (for there has never been a woman) is a member of the Cabinet (appointed by the Prime Minister), Speaker of the House of Lords, and he also presides over the Judicial Committee of the House of Lords when he chooses to take part in judicial business. The Lord Chancellor thus has executive, legislative and judicial functions, and he is a member of all three branches of government.

A matter which is likely to give rise to difficulty under the European Convention on Human Rights, with questions having been raised about whether the executive appointments in Britain are compatible with article 6 which guarantees the right to a fair trial before an independent and impartial tribunal. See Smith v. Secretary of State for Trade and Industry, The Times (15 October 1999) 31 (employment tribunals) and Starrs v. Procurator Fiscal Linlithgow, The Times (17 November 1999) 29 (temporary sheriffs). Meet the Challenge, supra note 4 at 61.

See R. Stevens, "Judges, Politics, Politicians and the Confusing Role of the Judiciary" in K. Hawkins, ed., The Human Face of the Law: Essays in Honour of Donald Harris (Oxford: Clarendon Press, 1997) 245 at 246. Hewart Lord Chief Justice of England 1922-40 (London: George G. Harrap \& Co., 1959) at 12646.

Though it is quite possible that the mouse proposed by Peach could evolve into something a bit more substantial; the proposed beast seems admirable but has quite limited powers. 
accordance with the criteria for appointment, but would ultimately be responsible for making the appointments. ${ }^{94}$

It has been suggested above that the system of judicial appointments needs to be radically overhauled, though even a career judiciary would need an independent appointments commission. In the absence of such a transformation, there is, in the interests of judicial independence, a case to be made for taking the power of appointment from the executive and vesting in an independent statutory commission, ${ }^{95}$ subject to confirmation by a parliamentary committee. ${ }^{96}$ But we should not exaggerate the virtue of a scheme of this kind. It may be argued that it is wrong in principle that senior judicial appointments should be made by a member of the Cabinet, and by one who is not popularly accountable (not even indirectly accountable to the House of Commons). It is true that there is no suggestion that judicial appointments are now abused by the government of the day. Yet, as a practical matter, public confidence in an institution depends not only on the system working fairly in a principled manner, but also on its appearing to do so. Justice must not only be done, it must also be seen to be done. Nevertheless, the arguments for an independent commission in the modern British context is effectively an argument of form over substance. An appointments commission working with the same material as the Lord Chancellor's Department is unlikely to perm significantly different results.

\section{B. Institutional Separation: A SUPREme Court}

The second concern that we have seen relates to the fact that senior judges are also a part of the legislature. This includes not just those who take part in the judicial business of the House, but also, at the time of writing, the Lord Chief Justice and the Master of the Rolls. All of these are entitled to give us the benefit of their wisdom on matters of current controversy in the legislative business of the House, and not all are shy about doing so. ${ }^{97}$ This too has become a hot issue for the constitutional reformers, with the radicals arguing in favour of an institutional separation of the judges from

The composition of such a body would have to be regulated by statute to ensure that it was not simply the Lord Chancellor's alter ego, and although the Lord Chancellor (or other ministers) might be empowered to make representations to such a Commission, it is the latter which would have to have the last word: for this purpose it would need to be robustly independent. For a good discussion of this proposal, see R. Brazier, "The Judiciary" in R. Blackburn \& R. Plant, eds., Constitutional Reform: The Labour Government's Constitutional Reform Agenda (London: Addison Wesley Longman, 1999) at c. 16. On which lawyers and judges are not the dominant voice.

\% It is important to emphasize (contra others) that a judicial appointments commission would not make the Bench more representative or accountable. It is true that a commission could be set targets in terms of gender and ethnic recruitment but so too could the Lord Chancellor's Department. So far as the accountability of the judiciary is concerned, it is true that an independent appointments commission could include non-governmental public representatives, perhaps even more than a token few (Brazier, ibid.) But this would not make the judges accountable (to anyone) for the way in which they discharged their duties, even if the independent commission was made accountable to Parliament for the way it exercises its powers.

97 They also play a useful part in the work of the House, chairing important scrutiny committees, such as the European Communities Committee. 
Parliament by means of the creation of a new Supreme Court. It is true that judges do not routinely take part in the legislative business of the House, and that when they do, they tend to eschew controversial political issues. ${ }^{98}$ It is also true that some important pieces of legislation are initiatives of the Law Lords: Contempt of Court Act 1981, s. 1099; Police and Criminal Evidence Act 1984, s. $78^{100}$; and the Defamation Act 1996 , s. $9 .^{101}$ But it is equally true that the judges are free to engage actively as legislators, as they did during the debates leading up to the Human Rights Act 1998, when several serving or retired Law Lords spoke in the second reading, and many others took part in the Committee and Report stages. ${ }^{102}$ To put it politely, there seems something not quite right about the spectacle of judges participating in the enactment of legislation designed to extend their own powers.

The existence of an institutionally distinct court is well established in other countries, and it is perhaps embarrassing even to be addressing this issue before (what is for the author) a foreign audience. Although there may be in principle a strong case for the institutional separation of the judges in this way as a means of enhancing judicial independence, ${ }^{103}$ it may again be a matter of form rather than substance. The point was addressed by the Royal Commission on the Reform of the House of Lords which acknowledges that some "mischief or inconvenience could arise if a Law Lords' participation in a debate or vote in the second chamber subsequently limited his or her (sic) ability to hear a related case," a problem thought to be enhanced by the Human Rights Act 1998 and the devolution legislation. But, as the Royal Commission pointed out, these problems could be overcome without the need for institutional separation: in the view of the Royal Commission "[t]he Lords of Appeal should set out in writing and publish a statement of the principles which they intend to observe when participating in debates and votes in the second chamber and when considering their eligibility to sit on related cases." 104 In truth, as a practical matter, institutional separation is seriously unlikely to enhance judicial independence because it is largely irrelevant to questions of representation and independence. ${ }^{105}$

A House for the Future, supra note 70.

Protecting journalists' sources, though it has been read very narrowly by the courts. See Secretary of State for Defence v. Guardian Newspapers, [1985] A.C. 339 (H.L.); S Lid. v. Morgan Grampian (Publishers), [1991] 1 A.C. 1 (H.L.). Cf Goodwin v. United Kingdom (1996), 22 E.H.R.R. 123.

Giving the courts discretion to refuse to admit evidence in criminal trials which has been unfairly obtained. Cf $R$. v. Sang, [1980] A.C. 402.

Allowing the defamation proceedings to proceed in circumstances where they were previously constrained by the Bill of Rights, 1689, (1 Will. \& Mary, sess. 2, c. 2), art 9. See Prebble v. Television New Zealand, [1995] 1 A.C. 321 (P.C.).

Ewing, supra note 18.

Ibid.

A House for the Future, supra note 70 at 94-95.

Although the point is not to be pressed too forcefully, there is a sense in which it could become less representative. If a new Supreme Court were to be created, it is unlikely that the Lord Chancellor would continue to have a presence: indeed one of the reasons for the creation of such a body is to manufacture a rigid separation of legislature and judiciary. Yet before we celebrate the importation of yet further American values into our constitutional arrangements, we should reflect on who the Lord Chancellor is and the benefits which his presence brings to the process of law-making. The Lord Chancellor is (among other things) the country's senior judge, appointed 


\section{Conclusion}

In the United Kingdom, great steps have been taken in recent years to modernize our political institutions, and to develop our democratic principles. The measures taken thus far include the devolution of legislative power to Scotland, Wales, and Northern Ireland; the removal of hereditary peers from the House of Lords; and the enactment of the Human Rights Act 1998. Although they will play a key role in resolving disputes about many of these modernizing initiatives, the judges have thus far escaped the attention of the modernizers. Indeed, the judicial branch has largely escaped the general democratizing initiatives of the 20th century. They remain an undemocratic institution that polices the democratic process by the application of values and principles which belong to a bygone era. There is much to be done if we are to have a modern and democratically responsive judiciary, not the least of which is the need to remove the legislative powers which the courts have managed to retain. There is no democratic case for a common law regime created and developed by political actors who can never be fully accountable in the true democratic sense. The survival of what is the real anachronism of the judicial process is, however, all the more reason for the application of appropriate democratic principles to the judicial branch, though there is a case for such application, whatever role the judges perform.

The case for a democratic judiciary becomes compelling once judges are also given responsibility for policing the democratic process itself. It is simply bizarre that

by the Prime Minister, and almost certainly in modem times, a member of the governing political party. As such, at least under a government of the Left, he brings to the position a political perspective which might otherwise not be heard, and represents in the senior judiciary a point of view which is singularly absent. As Conor Gearty has pointed out ("Human Rights \& Civil Liberties: Co-operation or Conflict?" Justice Annual Lecture, London, 7 October 1999), a good example of this point is provided by DDP v. Jones, [1999] 2 All E.R. 257, where the House of Lords was asked to decide whether those who use the public highway for the purpose of peaceful protest are trespassing in the sense that they are using the highway for a purpose other than a lawful purpose. In reversing the Divisional Court, the House of Lords divided 3:2, with the Lord Chancellor making a rare appearance, and in doing so bringing a spirit of Enlightenment to the proceedings. For the first time at the highest level in English law we have a recognition that "there is a public right of peaceful assembly on the highway" (ibid. at 265). It is true, however, that the creation of a separate body with its own home on the hill might well fuel demands for accountability. The process of creating a new institutional form and the existence of a new institution might on its own be enough to stimulate curiosity about these people and what they do. We might expect a greater press interest, and a cadre of reporters committed to writing about the new court: as in the United States where the Supreme Court is well covered by the New York Times in particular, and where there have emerged a number of distinguished and well informed journalists. This curiosity is likely to be stimulated still further by the fact that the creation of the new court would coincide with the conferring of new powers on the judges under the Human Rights Act 1998. We should recall, however, that the Royal Courts of Justice have a separate life on the Strand. But this institutional separation has not led to better exposure or accountability. What will lead to demands for greater accountability are the powers of the judges, rather than the buildings in which these powers are exercised. There is indeed a slight risk that institutional separation will reduce the accountability of the court. Although it may be anachronistic to have the Law Lords in the Legislature, it does nevertheless enhance the sense of accountability: when they choose to take part in debate, they do reveal something about themselves; this is not to be under-estimated. 
democratic institutions should be policed by institutions which fail to meet basic democratic values. This is not to say that the democratic principles applicable to a legislature are applicable in the same way to the courts. But there is a place for concepts of representativeness and accountability. There is, however, a need for flexibility in the development of principle, and in this context a need for a synthesis of principle: the need to reconcile the principles of representativeness and accountability on the one hand, with the principle of judicial independence on the other. The latter should not be diminished as an essential principle of liberal or social democracy, any more than the rule of law (of which the independence of the judiciary is an integral part) should not be diminished as a principle of democracy. Although important, the independence of the judiciary should not be viewed in isolation from other principles by being placed on too high a pedestal, and should not be used as a device to frustrate the operation of other democratic principles. It is, however, strongly arguable that independence would be reinforced by a judiciary which was simultaneously representative and accountable.

So where does this lead us? The requirement for a representative judiciary requires a Bench which at least reflects the nation in terms of gender, ethnic background, and political values. It also requires a Bench which is accessible to all, with access being determined by educational achievement and ability alone, without the need to establish success in a private labour market that places a premium on patronage at a number of levels. This reveals the need for a career judiciary. The requirement for an accountable judiciary requires a Bench which is accountable to those it governs, an obligation which requires accountability in terms of greater transparency and scrutiny. There is a role for a parliamentary commiteee in promoting both of these by confirming judicial appointments (particularly at the highest level) and by considering the way in which judicial power is exercised. The requirement for an independent judiciary would be strengthened rather than undermined by the implementation of these principles. There is also scope for considering whether judicial independence would be strengthened by the creation of a Judicial Appointments Commission (answerable to Parliament), and by the establishment of a new Supreme Court, though it is perhaps paradoxical that such initiatives are unlikely in practice to alter the composition of the Bench or to enhance its independence. 